\title{
МІФОЛОГЕМИ ПРО ВІЙСЬКОВІ ЗВИТЯГИ «БЛАГОВІРНОГО» КНЯЗЯ ОЛЕКСАНДРА НЕВСЬКОГО
}

\section{Ніколаюк Т. А.}

\section{ВСТУП}

Офіційні російські історики дедалі частіше спрямовують свої зусилля не для об'єктивного висвітлення подій минулого, а для створення історичних міфів. Авторка неодноразово зверталася до аналізу російських міфологем про власне історичне минуле $\mathrm{e}^{1,2,3,4}$. Особистість Олександра Невського найбільш міфологізована російськими істориками. Його постать стала майже культовою в сучасній Росії, що підтвердили результати масштабного опитування росіян у грудні 2008 року. Саме за Олександра Невського вони проголосували як за переможця в номінації «Ім'я Росії», визнавши його найвидатнішим діячем російської історії. За його кандидатуру проголосувало понад півмільйона людей.

Міфологізація постаті Олександра Ярославовича особливо активізувалася за часів правління Петра I, за наказом якого так звані «мощі» князя перенесли в побудовану нову столицю імперії Петербург та розташували у спеціально побудованій Олександро-Невській Лаврі. Імператору, який 20 років воював зі шведами за вихід у Балтійське море, було вкрай необхідно провести канонізацію «переможця над шведами у Невській битві», яким вважався Олександр Невський. Небезпідставно Петро I проголосив 30 серпня днем пам'яті Олександра Невського - саме в цей день було укладено Ніштадський мир із Швецією. У 1725 році в Російській імперії для винагороди за видатні військові заслуги був затверджений орден Святого Олександра Невського. Імператриця Єлизавета в 1753 році наказала помістити мощі Олександра в дорогоцінну срібну раку. Надалі стали щорічно

${ }^{1}$ Ніколаюк Т.А. Світоглядні міфологеми у тлумаченні історичного минулого України та Росії. Практична філософія. 2018. № 4. С. 88-100.

${ }^{2}$ Ніколаюк Т.А. Світоглядні міфологеми у тлумаченні історичного минулого України та Росії. Частина 2. Практична філософія. 2019. № 1. С. 88-103.

3 Ніколаюк Т.А. Міфологізовані правителі Московії. Частина 1. Дмитро Донський - анафемований святий. Практична філософія. 2019. № 2. С. 108-113.

${ }^{4}$ Ніколаюк Т.А. Міфологізовані правителі Московії. Частина 2. Міфологеми про антитатарську діяльність московського князя Дмитра Івановича. Практична філософія. 2019. № 4. С. 90-99. 
проводити спеціальний хресний хід із петербурзького Казанського собору до Олександро-Невської Лаври.

У 1942 році, в розпал війни 3 нацистською Німеччиною, в Радянському Союзі був заснований орден Олександра Невського, хоча героїзація постаті князя розпочалася 31938 року в кінострічці «Олександр Невський» режисера С. Ейзенштейна. У фільмі показано, як Олександр Ярославович вдало воював проти зовнішніх ворогів Новгородської республіки - західних католицьких народів, як мудро він командував арміями та здійснював героїчні подвиги. Керівник комуністичної держави диктатор Й. Сталін змусив видатного режисера сформувати в суспільній свідомості радянських людей образ великого історичного діяча, військові перемоги якого захистили майбутню православну державу від католицької експансії лівонців, шведів та тевтонців. Зрозуміло, що 3 початком радянсько-німецької війни 1941-1945 років фільм активно використовувався сталінською пропагандою для підняття духу радянських солдат, доводячи можливість перемоги над німцями, яких свого часу погромив на Чудському озері «святий князь» Олександр Невський.

Сучасна російська православна церква підкреслює так званий «православний патріотизм благовірного і святого князя Олександра», використовуючи його «героїчні битви з католиками» для виховання в росіян, з одного боку, любові до «православної Віри і Батьківщини», а $з$ другого - ненависті до іноземців.

Треба зазначити, що ще на початку XX століття геніальний письменник і філософ Л. Толстой піддав сумніву такий патріотизм, вважаючи його обманом, який влада використовувала для прикриття своїх неподобств. Процитуємо російського класика: «Мне уже несколько раз приходилось высказывать мысль о том, что патриотизм есть в наше время чувство неестественное, неразумное, вредное, причиняющее больщую долю тех бедствий, от которых страдает человечество, и что поэтому чувство это не должно быть воспитываемо, как это делается теперь, а напротив, подавляемо и уничтожсаемо всеми зависящими от разумных людей средствами».

«То, что называется патриотизмом в наше время, есть только, с одной стороны, известное настроение, постоянно производимое и поддерживаемое в народах школой, религией, подкупной прессой в нужном для правительства направлении, с другой - временное, производимое исключительными средствами правящими классами,

5 Толстой Л.Н. Патриотизм и правительство. Полное собрание сочинений в 90 томах. Т. 90. Дневники. Письма, 1835-1910. Москва, 1958. С. 425. URL: http://tolstoy.ru/upload/iblock/e8e/90_tom.pdf (дата звернення: 31.10.2020). 
возбуждение низших по нравственному и умственному даже уровню людей народа, которое выдается потом за постоянное выражение воли всего народа» ${ }^{6}$.

«...Но как же может быть патриотизм добродетелью в наше время, когда он требует от людей прямо противоположного тому, что составляет идеал нашей религии и нравственности, не признания равенства и братства всех людей, а признания одного государства и народности преобладающими над всеми остальными. Но мало того, что чувство это в наше время уже не только не есть добродетель, но несомненный порок; чувства этого, т. е. патриотизма в истинном его смысле, в наше время и не может быть, потому что нет для него ни материальных, ни нравственных оснований» ${ }^{7}$.

"...Патриотизм в самом простом, ясном и несомненном значении своем есть не что иное для правителей, как орудие для достижения властолюбивых и корыстных целей, а для управляемых - отречение от человеческого достоинства, разума, совести и рабское подчинение себя тем, кто во власти. Так он и проповедуется везде, где проповедуется патриотизм. Патриотизм есть рабство».

\section{1. «Повесть о житии и о храбрости благоверного и великого князя Александра...»}

Офіційна біографія Олександра Невського базується на літописній "Повести о житии и о храбрости благоверного и великого князя Александра". Саме там описані так звані «перемоги» Олександра Ярославовича в битвах на Неві та на льоду Чудського озера. Відразу зазначимо, що цей опис «героїчних діянь» князя Олександра характеризується абстрактністю, в ньому не датована жодна описана подія, автор майже не називає історичних імен і не завжди точний в описі подій.

Повість була створена за часів правління сина Олександра Ярославовича Дмитра Олександровича. Спочатку іï автор зазначає: «Я, худой и многогрешный, недалекий умом, осмеливаюсь описать житие святого князя Александра, сына Ярославова, внука Всеволодова. Поскольку слышил я от отиов своих и сам был свидетелем зрелого возраста его, то рад был поведать о святом, и честном, и славном житии его... Хотя и прост я умом, но все же

${ }^{6}$ Толстой Л.Н. Христианство и патриотизм. Полное собрание сочинений в 90 томах. T. 39. Статьи 1893-1898. Москва, 1956. С. 60. URL: http://tolstoy.ru/upload/iblock/ 08c/08c43ef984906280a7a38dd797d2af99.pdf (дата звернення: 31.05.2020).

\footnotetext{
${ }^{7}$ Там само. С. 61 .

${ }^{8}$ Там само. С. 65
} 
начну, молитвою святой Богородиџь и помощуью святого князя Александра» ${ }^{9}$.

Більшість дослідників ще за радянських часів зазначали, що «Повесть о житии Александра Невского» можна вважати типовим літературним твором у жанрі княжого життєпису. Як слушно стверджував ще у 1940 році академік М. Тихомиров, «Повесть о житии...» належить, перш за все, до галузі літератури, а не історії. У тексті повісті князь Олександр Невський подається як святий заступник «Руської землі», а історичні події в ній $є$ другорядним фоном. На думку академіка, цей твір був спеціально створений для вихваляння князя Олександра Ярославовича як непереможного воїна, подібного до римського імператора Веспасіана, давньоєврейського героя Самсона, легендарного царя Давида ${ }^{10}$.

Це підтверджують нові офіційні наукові роботи. Наприклад, наведемо цитату 3 російського словника «Литература и культура Древней Руси: Словарь-справочник»: «Видимо, вскоре после его смерти (Александра Невского) была написана «Повесть о житии Александра Невского», в которой создается идеальный образ правителя. Повесть дошла до нас в различных редакциях XIII-XVIII вв. История ее текста необычайно сложна, многое остается пока спорным. Составление текста повести относят к 80-м годам XIII 8. u связывают с именем сына Александра Невского Дмитрия Александровича, a также с именем митрополита Киевского $u$ Владимирского Кирилла. Ряд исследователей считают, что первая редакция повести создана во Владимире при монастыре Рождества Богородицы, где было погребено тело князя Александра и возникло его почитание. На протяжении нескольких веков первая редакция неоднократно перерабатывалась. $В$ настоящее время известно 13 редакиий произведения» ${ }^{11}$.

${ }^{9}$ Повесть о житии и о храбрости благоверного и великого князя Александра. Подготовка текста, перевод и комментарии В.И. Охотниковой. Библиотека литературы древней Руси. Том 5. Электронные публикации Института русской литературы (Пушкинского Дома) PAH. С. 1. URL: http://lib.pushkinskijdom.ru/ Default.aspx?tabid=4962 (дата звернення: 31.10.2020).

10 Тихомиров М.Н. Сражение на Неве. Военно-исторический журнал. 1940. № 7(12). C. 99.

11 Литература и культура Древней Руси: Словарь-справочник / О.М. Анисимова, В.В. Кусков, М.П. Одесский, П.В. Пятнов. Под ред. В.В. Кускова. Москва, 1994. C. 42. URL: http://history.org.ua/LiberUA/5-06-002874-7/5-06-002874-7.pdf (дата звернення: 30.10 .2020$)$. 


\section{2. Міф про католицьку загрозу}

Згідно з «Повестью о житии...», Олександр Невський у 15-річному віці був посаджений князювати в Новгороді своїм батьком Ярославом Всеволодовичем. Деякі радянські історики стверджують, що Олександр Невський на чолі з новгородським військом нібито «відбив хрестовий похід католиків на православну Русь». На їхню думку, похід був оголошений папою Григорієм IX, який у папській буллі від 9 грудня 1237 року звертається до шведського архієпископа із закликом організувати «хрестовий похід» у Фінляндію «проти тавастів» та їхніх «близьких сусідів».

Так, радянський історик Б. Рамм зазначає, що «очевидно, что призывая крестоносиев уничтожать “врагов креста", папа имел в виду наряду с тавастами также карелов и русских, в союзе с которыми тавасты в эти годы энергично противились католической экспансии» ${ }^{12}$.

Однак сучасний російський дослідник О. Нестеренко зазначає, «что под «близкими соседями» Папа подразумевает не русских, а многочисленные языческие финские и карельские племена (в русских летописях ямь, емь, сумь, корела, ижора и др.), названий которых в далеком от Скандинавии Риме просто не знали... Направление «крестового похода» в этой булле тоже указано предельно ясно: Финляндия. Ни одного папского послания, в котором провозглашается «крестовый поход» на Русь, не обнаружено»" ${ }^{13}$.

Варто нагадати, що римські папи ніколи не називали православних язичниками, вони вважали їх схизматиками, єретиками, але не язичниками, бо усвідомлювали, що православ'я - це гілка християнства. Тому в буллі папи Григорія IX йшлося не про хрестовий похід на православних новгородців та псковичів, як це подається деякими російськими істориками, а про християнізацію язичників-фінів.

Крім виконання місіонерської християнської місії серед язичників, німецькі i шведські правителі мріяли захопити контроль над торгівельними шляхами в Балтійському регіоні. До початку XIII століття торгівля на Балтиці здійснювалася здебільшого скандинавськими купцями і новгородцями, які доставляли товари на човнах, які не були пристосовані для виходу на далеку від берега відстань. До того ж новгородці звикли будувати власні водні торгівельні порти лише біля берегів річок.

12 Рамм Б.Я. Папство и Русь в X-XV вв. Москва-Ленинград, 1959. URL: http://a-nevsky.ru/library/papstvo-i-rus8.html (дата звернення: 02.11.2020)

${ }_{13}$ Нестеренко А.Н. Александр Невский. Кто победил в Ледовом побоище. Москва, 2006. URL: https://may.alleng.org/d/hist/hist093.htm. (дата звернення: 30.10.2020) 
Ситуація змінилася, коли внаслідок запровадження нових технічних інновацій, у німецьких торговців з'явилась можливість використовувати глибоководний багатотоннажний вітрильник, що давав змогу орієнтуватися за Сонцем і зірками, вибирати оптимальний маршрут у відкритому морі, плавати далеко від берегів і перевозити велику кількість товарів. I коли у середині XIII століття німецькі купці почали перевозити товари виключно за допомогою великотоннажних кораблів, новгородські купці втратили конкурентні переваги перед іноземцями та почали поступатися сусіднім країнам впливом на економічний простір Балтійського регіону.

Це призвело до розгортання конфліктів між новгородцями та сусідами за контроль над морським узбережжям, придатним для побудови нових торгівельних факторій і портів. Незначний прикордонний конфлікт на березі Неви між шведськими торговцями та новгородцями у 1240 році стараннями російських істориків перетворився на «велику битву» Олександра Невського «в ім'я захисту православної Русі від католицької навали і боротьбу за незалежність всієї Русі».

\section{3. Міфологеми про «Невську битву»}

Розглянемо тепер реальний перебіг подій на річці Неві, що відбулися 15 липня 1240 року, спираючись на інформацію з історичних документів «Новгородской первой летописи старшего извода» ${ }^{14}$, «Новгородской четвертой летописи» ${ }^{15}$ та «Повести о житии...» Відповідно до текстів цих джерел, у 1240 році величезний шведський флот («в кораблихъ множьство много зЂло») під командуванням шведського короля увійшов у річку Неву на кордоні Новгородської республіки й отаборився на узбережжі річки Іжори. Князь Олександр швидко дізнався про їх прибуття, i, не звернувшись за допомогою до свого батька, лише $з$ невеликою дружиною новгородців і ладожанців 15 липня атакував шведський табір і отримав блискучу перемогу над шведським військом. Внаслідок цієї битви загинула величезна кількість шведів «и множество много ихъ паде», а інші в «посрамлени отъидома». До того ж під час поєдинку хоробрий князь Олександр поранив шведського короля в обличчя гострим списом ${ }^{16}$.

${ }^{14}$ Полное собрание русских летописей (ПСРЛ). Новгородские летописи. Т. III. Издание 1-е. Санкт-Петербург, 1841. Новгородская первая летопись. С. 52-53. URL: http://psrl.csu.ru/toms/Tom_03.shtml (дата звернення 31.05.2020).

15 Полное собрание русских летописей (ПСРЛ). Новгородские и Псковские летописи. Новгородская четвертая летопись. T. IV. Санкт-Петербург, 1848. С. 35. URL: http://psrl.csu.ru/toms/Tom_04.shtml (дата звернення 31.05.2020).

16 Полное собрание русских летописей (ПСРЛ). Новгородские и Псковские летописи. Новгородская четвертая летопись. T. IV. Санкт-Петербург, 1848. С. 35. URL: http://psrl.csu.ru/toms/Tom_04.shtml (дата звернення 31.05.2020). 
А тепер звернемось до іншого джерела - шведської “Хроники Эрика”, свідчення якої повністю спростовують версію «Новгородской первой летописи старшего извода», «Новгородской четвертой летописи» та «Повести о житии...» В «Хронике Эрика» відображені визначні події шведської історії, які відбувалися від сорокових років XII століття до 1430 року. Ї̈ автор інформує про абсолютно всі перемоги і поразки шведської армії, що відбулися за цей історичний період ${ }^{17}$. Але викликає здивування відсутність в «Хронике Эрика» опису Невської битви. Оскільки, наприклад, згідно з дописами автора «Повести о житии...», внаслідок «великої перемоги» князя Олександра шведське військо втратило величезну кількість воїнів, i шведський хроніст обов'язково мусив про це згадати.

Спробуємо розібратися, що насправді відбулося. У разі уважного ознайомлення з інформацією літописів про дії Олександра Ярославовича виникає питання: чому він, дізнавшись про прибуття величезного шведського флоту, не звернувся до свого батька, князя Ярослава Всеволодовича, за допомогою? Чому, не оголосивши загальне зібрання новгородського ополчення, 3 невеликою кількістю людей кинувся назустріч величезного іноземного флоту? Будь-який військовий керівник у такій ситуації грунтовно підготувався б до битви, звернувся б за допомогою до князів-сусідів. Дивують також дії шведських воїнів: чому замість просування у глибину Новгородської землі і нападу на велике торгівельне місто вони зупинилися на кордоні Новгородської республіки, розкинувши табір?

На ці питання можна дати чіткі відповіді, якщо прийняти версію історика О. Нестеренка, який стверджує, що на прикордоння Новгородської держави прибули на кораблях не воїни, а шведські купці для здійснення перемовин про торгівлю. Тому вони розкинули табір і чекали перемовників із Новгорода. Але замість мирних послів дочекалися від князя Олександра, який із невеликим загоном здійснив на них розбійницький напад. Для розправи 3 купцями «героїчному князю» не потрібне було велике військо і допомога батька.

У збройному нападі на невелику кількість торговців немає ніякої військової слави, бо пограбування купців в усі часи вважалося розбоєм та засуджувалося. Тому, мабуть, цей прикрий випадок й не увійшов у шведську хроніку. Навпаки, новгородські, а пізніше й московські літописці, замість осуду за розбій, проголосили Олександра Ярославовича захисником православної Вітчизни. Треба зауважити,

${ }^{17}$ Хроника Эрика / Составитель, ответственный редактор и редактор перевода А.А. Сванидзе. Перевод со старошведского А.Ю. Желтухина. Второе издание, исправленное и дополненное. Москва, 1999. 254 с. 
що деякі сучасні історики розходяться в думках щодо того, був шведський загін купецьким чи розвідницьким. Але те, що він був нечисленним, більшість дослідників вже не заперечує.

Деякі факти 3 «Новгородской первой летописи старшего извода» дійсно підтверджують незначність військової сутички, яка згодом почала трактуватися російськими істориками як «грандіозна Невська битва». Літописець вказує, що безліч ворогів впало, але одночасно розповідає про дуже малі втрати новгородців - лише 20 осіб, причому перераховує їх поіменно: «Новгородець же ту паде: Костянтинь Луготиииць, Гюрята Пинещиинич, Намъ стъ, Дрочило Нездыловъ сынъ кожевника, а встхъ 20 мужь с ладожаны, или мне, богъ въвть. Князь же Опександръ съ новгородичи и с ладожаны придоша вси здрави въ своя си, схранени богомь и святою Софьею и молитвами встьъ святыхъ» ${ }^{18}$. Вислів із літопису «или мне, богъ въстъ» вказує на те, що автор достовірно не знав реальної кількості полеглих у битві новгородців. Тому деякі дослідники припускають, що їх було не 20, а менше. Мала чисельність загиблих новгородців доводить, що в липні 1240 року на Неві відбулася незначна військова сутичка, а не вигадане пізніше «велике побоїще».

Тому можна вважати, що новгородські та московські церковні літописці спеціально створили міф «про велику битву князя Олександра Ярославовича 3 ворогами-католиками». Недарма царський історик С. Соловьов підкреслював: «Зная..,, с каким намерением приходили шведы, мы поймем то религиозное значение, которое имела Невская победа для Новгорода и остальной Руси; это значение ясно видно в особенном сказании о подвигах Александра: здесь иведы не иначе называются как римлянами - прямое указание на религиозное различие, во имя которого предпринята была война» ${ }^{19}$.

Так звана «Невська перемога» не принесла ніяких преференцій Новгородській державі. Одразу після неї новгородці вигнали 3 міста князя Олександра із родиною ${ }^{20}$. Через кілька років «вщент розбиті шведи» взяли під контроль все північне узбережжя Фінської затоки i примусили фінське плем'я Смь сплачувати данину, яке воно раніше сплачувало Новгороду.

${ }^{18}$ Полное собрание русских летописей (ПСРЛ). Новгородские летописи. Т. III. Издание 1-е. Санкт-Петербург, 1841. Новгородская первая летопись. С. 53. URL: http://psrl.csu.ru/toms/Tom_03.shtml (дата звернення 31.05.2020).

19 Соловьев С.М. История России с древнейших времен. Соловьев С.M. Сочинения. Москва, 1993. Т. 3. С. 174.

${ }^{20}$ Полное собрание русских летописей (ПСРЛ). Новгородские летописи. Т. III. Издание 1-е. Санкт-Петербург, 1841. Новгородская первая летопись. С. 53. URL: http://psrl.csu.ru/toms/Tom_03.shtml (дата звернення 31.05.2020). 
Пізніше, у 1252 році, Олександр Невський здійснить безуспішний військовий похід на ці землі, сподіваючись відвоювати їх у шведів. Автор «Новгородской первой летописи старшего извода» повідомляє про цей похід: “В лгтоо 6764.... И поиде съ своими полкы князь и с новгородии; и бысть золь путь, акыже не видала ин дни, ни ночи; и многымъ шестникомъ бысть пагуба, а новгородиевъ богъ сблюде. И приде на землю Бмьскую, овыхъ избита, а другыхъ иэъимаша; и придоша новгородичи с княземь Олександромь вси эдорови» ${ }^{21}$. Лише через чотири століття російському імператору Петру I вдалося відвоювати у шведів територію в гирлі Іжори і «прорубати вікно в Європу».

Після з'ясування всіх фактів, авторка приєднується до думки істориків О. Нестеренко, Дж. Феннела ${ }^{22}$, І. Данілевського ${ }^{23}$, які наполягають на версії про здійснення князем Олександром Ярославовичем грабіжницького нападу на шведів у липні 1240 року. Скоріш за все шведський загін створив на березі Неви військово-торгівельний опорний пункт. Це була звична шведська тактика - побудувати замок, пересунути на кілька кілометрів кордон і отримати контроль над стратегічно важливою місцевістю. Але оскільки це була Новгородська територія, такі дії шведів викликали невдоволення новгородських купців, які не бажали ділитися із ними своїм монопольним прибутком i контролем над балтійськими торгівельними шляхами. Тому вони покликали до себе князя Олександра, який у липні 1240 року зіткнувся із невеликим загоном шведських розвідників або купців та на деякий час вигнав їх із північного кордону Новгородської держави.

\section{4. Історичні джерела про «Льодове побоӥще»}

Згідно $з$ літописами, ця битва відбулася 5 квітня 1242 року. В уяві росіян вона змальовується як битва, в якій з обох сторін брали участь тисячі воїнів на засніжених полях і замерзлому Чудському озері, під лід якого під вагою власних доспіхів провалюються тевтонські хрестоносці. Однак, як стверджує сучасний російський історик I. Данилевський, до виходу у 1938 році фільму С. Ейзенштейна «Олександр Невський» вивчення подій «Льодового побоїща» навіть не входило

${ }^{21}$ Полное собрание русских летописей (ПСРЛ). Новгородские летописи. Т. III. Издание 1-е. Санкт-Петербург, 1841. Новгородская первая летопись. С. 56. URL: http://psrl.csu.ru/toms/Tom_03.shtml (дата звернення 31.05.2020).

${ }_{22}$ Феннел Дж. Кризис средневековой Руси. 1200-1304 гг. Москва, 1989. 291 с. URL: http://booksonline.com.ua/view.php?book=35808 (дата звернення: 31.05.2020).

${ }_{23}^{23}$ Данилевский И. Н. Ледовое побоище: смена образа. Отечественные записки. 2004. № 5. URL: http://www.strana-oz.ru/2004/5/ledovoe-poboishche-smena-obraza (дата звернення: 01.11.2020). 
у вузівські лекційні курси, бо цей бій не мав для істориків загальнонаціонального значення. I лише в часи Другої світової війни радянськими пропагандистами була створена міфологема про геополітичне значення цієї битви, про жахливу поразку німецьких лицарів, після якої у XIII столітті німецький наступ на Русь був остаточно припинений.

Для грунтовного розгляду міфологеми про побоїще на Чудському озері нам потрібно буде звернутися до середньовічних літописів $\mathrm{i}$ хронік. За місцем свого походження всі ранні письмові відомості XIII ст. про так зване «Льодове побоїще» можна розділити на групи: I - новгородські, які увійшли до складу «Новгородской 1-й летописи старшого извода»; II - псковські, які увійшли до складу «Псковских 1-й, 2-ц̌ $i$ 3-й летописей»; III - ростовські, які увійшли до складу «Суздальской летописи»; IV - суздальські, які увійшли до складу «Лаврентьевской летописи»; V - володимирські ранні, які знайшли відбиток в «Повести о житии Александра Невского первой редакизии». Найбільш повний опис битви міститься в «Новгородской 1-й летописи стариого извода». Щодо «Лаврентьевской летописи», то вона має два списки - «Суздальскую летопись по Лаврентьевскому списку» i «Суздальскую летопись по Академическому списку».

У шосту групу історики умовно зараховують володимирські пізні звістки, які містяться у «Владимирском летописце» XVI cm.

Кожна з перших п'яти груп звісток XIII ст. виникла незалежно одна від одної, маючи своїм прямим і безпосереднім джерелом події, що відбулися на льоду Чудського озера на початку квітня 1242 року.

До нас також надійшло кілька західних хронік, автори яких описують битву на Чудському озері. Найдавніша 3 них - «Стариая ливонская рифмованая хроника», в якій битва між рицарями та новгородським військом описується у 12 тисячах рифмованих віршів. Вона збережена у двох пергаментних рукописах - Ризькій XIV століття та Гейдельберзькій XV століття. Ця хроніка - єдиний західноєвропейський документ, який містить автентичні відомості про «Льодове побоїще».

У більш пізніх хроніках (так званих «Хроніках тевтонського ордена», виданих у XIV столітті Германом фон Вартбергом та в «Історії Лівонії», написаних Йоганном Ремером у XVI столітті), відомості про цю поразку німецьких воїнів у XIII столітті опираються на текст саме «Старией ливонской рифмованой хроники». Тому саме ії зміст вважається головним джерелом для висвітлення битви тевтонців проти новгородців на Чудському озері.

Що стосується висвітлення цих подій у «Повести о житии...», то, як ми вже згадували, необхідно враховувати його історичну 
недостовірність. Її автор довільно, без будь-якого датування, переказує сюжет про битву, використовуючи текст «Новгородской первой летописи старшого извода». До того ж для посилення ефекту від описаних подій автор надає сакрального значення постаті та діянню князя Олександра, додаючи інформацію про святих Бориса і Гліба, втручання Бога у діяння князя, православну духовність та інше. Тому «Повесть о житии...» можна вважати не історичним документом, а недостовірною компіляцією подій.

\section{5. Міфологеми про «Льодове побоӥще»}

На початку «Старшей ливонской рифмованой хроники» іï автор інформує читача про першопричину протиборства Тевтонського ордену i Новгородської республіки, а саме: про захоплення тевтонськими лицарями міста Ізборська, яке відбулося на прохання єпископа Германа $з$ метою захистити християнство. Зазначимо, що захист віри завжди використовували для виправдання територіальних захоплень, і в цьому тевтонські лицарі нічим не відрізнялися від інших.

Хроніка сповіщає, що «... пошли на них [русских] приступом, захватили у них замок. Этот замок назывался Изборск. Ни одному русскому не дали [уйти] невредимым. Кто защищался, тот был взят 6 плен или убит. Слышины были крики и причитания: в той земле повсюду начался великий плач». Далі автор хроніки повідомляє про спробу жителів Пскова відбити Ізборськ у тевтонців та про поразку псковичів. Лицарі навіть оточили Псков, і лише укладання мирного договору врятувало місто від захоплення: «Под Изборском они [русские] потерпели поражение... Братья-рыцари разбили свои палатки перед Псковом на красивом поле. Епископ и мужи короля также очень удобно расположились лагерем... Русские изнемогли от боя под Изборском: они сдались ордену, так как опасались [большего] несчастья. Тогда провели переговоры о мире. Мир был заключен тогда с русским на таких условиях, что Герпольд, который был их князем, по своей доброй воле оставил замки и хорошие земли в руках братьевтевтонцев, чтобы ими управлял магистр. Тогда штурм [Пскова] не состоялся» ${ }^{24}$.

Після укладання миру тевтонське військо зібралося і пішло з-під Пскова додому, залишивши в місті двох лицарів і невеликий загін німців, якому доручили охороняти завойовану землю. Князь Ярослав

24 Старшая ливонская рифмованная хроника. Средневековые исторические источники востока и запада. С. 2075-2160. URL: http://www.vostlit.info/Texts/rus12/ Livl_Alte_Reimschronik/text1.phtml?id=827 (дата звернення: 31.05.2020). 
Володимирович, який віддав лицарям місто, уклав із ними мирний договір та залишився в місті як намісник.

Слід було чекати, що в подальшому новгородці мали якось відреагувати на те, що сусіднє торгівельне місто Псков захоплене німцями. Хроніка нам пояснює цей факт таким чином: «На Руси есть город, он называется Новгород. До [новгородского] князя дошло это известие, он собрался со многими отрядами против Пскова... Туда он прибыл с большой силой; он привел много русских, чтобы освободить псковичей. Этому они от всего сердиа обрадовались. Когда он увидел немиев, он после этого долго не медлил, он изгнал обоих братьеврыцарей, положил конеи их фогтству, и все их слуги были прогнаны. Никого из немцев там не осталось: русским оставили они землю... Новгородский князь опять ушёл в свою землю. После этого не долго было спокойно» ${ }^{25}$.

Зауважимо, що в цьому абзаці жодного разу не згадується Олександр Невський, а тільки новгородський князь, імені якого хроніст не вказав. Але в «Повести о житии...» й «Новгородской первой летописи старшого извода» повідомляється, що саме Олександр Ярославович звільнив Псков від німців ${ }^{26}$. Тобто маємо від агіографів Олександра Невського пряму фальсифікацію - свідчення про звільнення нібито князем Олександром Ярославичем міста Пскова від тевтонців замість невідомого новгородського князя 3 німецької хроніки.

У подальшому описі подій іноземний хроніст знову інформує читача про участь у військових подіях новгородського князя, не повідомляючи його імені. Стає зрозумілим, що хроніст мав на увазі не Олександра Невського, а когось іншого. Бо автор хроніки надалі розповідає про діяння іншого князя - Олександра суздальського, який, пограбувавши місцевих жителів, підпалив їхні домівки: «Есть город большой и широкий, который также расположен на Руси: $u$ называется он Суздаль. Александром звали того, кто в то время был его князем. Он приказал своему войску готовится к походу. Русским были обидны их неудачи; быстро они приготовились. Тогда выступил Александр и с ним многие другие русские из Суздаля. Они имели бесчисленное количество луков, очень много красивейших доспехов. Их знамена были богаты, их илемы излучали свет. Так направились

25 Старшая ливонская рифмованная хроника. Средневековые исторические источники востока и запада. C. 2175-2200. URL:http://www.vostlit.info/Texts/rus12/ Livl_Alte_Reimschronik/text1.phtml?id=827 (дата звернення: 31.05.2020).

${ }^{26}$ Полное собрание русских летописей (ПСРЛ). Новгородские летописи. Т. III. Издание 1-е. Санкт-Петербург, 1841. Новгородская первая летопись. С. 53. URL: http://psrl.csu.ru/toms/Tom_03.shtml (дата звернення 31.05.2020). 
они в землю братьев-рыцарей, сильные войском. Тогда братья-рыщари, быстро вооружившись, оказали сопротивление; но их [рыцарей] было немного. А в Дерпте узнали, что пришел Александр с войском в земли братьев-рыиарей, чиня грабежи и пожары» ${ }^{27}$. Як бачимо, хроніст відрізняс двох князів - переможця над німцями під Псковом новгородського князя та суздальського Олександра, який на початку війни відзначився лише своїми грабунками.

У наступному абзаці автор хроніки вказує на нечисленність війська лицарів, які вирішили покарати за розбійницьку акцію суздальського князя Олександра: «Епископ не оставил это без внимания, быстро велел мужам епископства поспешить в войско братьев-рыцарей для борьбы против русских. Что он приказал, то и произошло. Они после этого долго не медлили, они присоединились к силам братьев-рыцарей. Они привели слишком мало народу, войско братьев-рыцарей было также слишком маленьким, однако они пришли к единому мнению атаковать русских» ${ }^{28}$.

Далі в "Старшей Ливонской рифмованой хронике» описується хід військової операції: «Немџь начали с ними бой. Русские имели много стрелков, которые мужественно приняли первый натиск, [находясь] перед дружиной князя. Видно было, как отряд братьев-рыщарей одолел стрелков; там был слышен звон мечей, и видно было, как рассекались илемы. С обеих сторон убитые падали на траву. Те, которые находились в войске братьев-рыцарей, были окружены. Русские имели такую рать, что каждого немия атаковало, пожалуй, шестьдесят человек. Братья-рыцари достаточно упорно сопротивлялись, но их там одолели. Часть дерптиев вышла из боя, это было их спасением, они вынужденно отступили. Там было убито двадиать братьеврыцарей, а шесть было взято в плен. Таков был ход боя. Князь Александр был рад, что он одержал победу. Он возвратился в свои земли. Однако эта победа ему стоила многих храбрых мужей, которым больше никогда не идти в поход» ${ }^{29}$.

Тобто маємо від агіографів Олександра Невського ще одну фальсифікацію - в німецькій хроніці Олександр Ярославович згадується як суздальський князь, і він бився з нечисленним військом лицарів, що суперечить свідченням новгородських та суздальських літописів «про величезне побоїще на Чудському озері».

27 Старшая ливонская рифмованная хроника. Средневековые исторические источники востока и запада. С. 2205-2225. URL: http://www.vostlit.info/Texts/rus12/ Livl_Alte_Reimschronik/text1.phtml?id=827 (дата звернення: 31.05.2020).

${ }_{28}$ там само. C. $2225-2230$.

${ }^{29}$ Там само. C. $2240-2265$. 
Автор «Новгородской первой летописи стармего извода» надає власну версію подій. Він інформує, що влітку 1240 року німці дійсно вщент розбили псковську армію під Ізборськом, але Пскова вони не змогли захопили, хоча підпалили посад. Простоявши під містом тиждень, німецька армія без укладання миру залишила псковську землю. Псковом почав керувати боярин Твердило Іванович, який разом із німцями «воюя села Новгородские» ${ }^{30}$. I саме після цього новгородці чомусь вигнали князя Олександра 3 міста. Літописець ніяк не пояснює цей дивний факт.

Але після побудови німцями взимку 1241 року на відстані 35 км від Новгорода фортеці, «новгородии же послаша к Ярославу по князя, $u$ дасть имь сына своего Андрея» ${ }^{31}$. Про діяльність Андрія як новгородського князя літописець не повідомляє жодного слова. Надалі новгородці чомусь знову вимагають від князя Ярослава повернути до їхнього міста саме Олександра.

I, як свідчить літописець, влітку 1241 року Олександр Ярославович повернувся до Новгорода і очолив військову адміністрацію міста. Таким чином, автор літопису повідомляє про досить дивну поведінку новгородців, які після сутички із шведами вигнали князя Олександра, а потім майже одразу запросили його повернутися.

Влітку 1241 року князь Олександр вирушив у похід, захопив місто Копор'є. У 1242 році разом із суздальським військом брата Андрія Олександр перетнув кордон та вдерся на територію Тевтонського ордену. А далі, чомусь не згадуючи Андрія, літописець розповідає про звільнення саме Олександром Пскова, про здійснення князем військових акцій проти тевтонців: «пусти полкъ все въ зажитія». Як стверджує автор, тевтонці дали відсіч новгородським військам, Олександр зазнав серйозної поразки і був вимушений стягнути свої військові сили на лід Чудського озера. Тевтонці, підтримані естонцями, вишикувались бойовим клином вперед i атакували новгородські війська. Розпочавши наступ, німецькі лицарі проникли вглиб оборонних ліній ворога, але все одно були розгромлені новгородцями: «и бысть съча ту велика Нъмиемъ и Чюди» ${ }^{32}$. Полонених німецьких воїнів переможці відправили у Новгород, а пізніше тевтонці вимушені були звільнити захоплені новгородські та псковські території для повернення своїх полонених додому.

${ }^{30}$ Полное собрание русских летописей (ПСРЛ). Новгородские летописи. Т. III. Издание 1-е. Санкт-Петербург, 1841. Новгородская первая летопись. С. 53. URL: http://psrl.csu.ru/toms/Tom_03.shtml (дата звернення 31.05.2020).

\footnotetext{
31 Там само.

${ }^{32}$ Там само. С. 53-54.
} 
Таким чином, за свідчення «Новгородской первой летописи старшего извода» із тевтонцями розпочали воювали два князі. А потім участь князя Андрія у битві на Чудському озері зовсім не згадується. Але, порівнюючи свідчення 3 двох літописів - «Суздальской летописи Лаврентьевского списка» та «Суздальской летописи по Академическому списку», уважний дослідник зверне увагу на суттєву різницю у повідомленні щодо особи, яку суздальський літописець вважає переможцем у «Льодовому побоїщі». У «Суздальской летописи Лаврентьевского списка» головним героєм битви

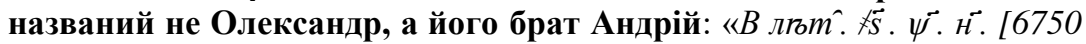
(1242)] Великъии княз Ерославъ посла сна своюго Андрга в Новъгородъ Великъии в помочь Єллександрови на Нтыми и побъдиша се за Плесковом на шзерг и полонъ многъ плтьниша $и$ възвратися Андргы|л. 165||и къ шйю своєму с чстьью» ${ }^{33}$.

Водночас автор «Суздальской летописи по Академическому списку» героєм «побоїща» вважас князя Олександра Ярославовича: «B лето 6750(1242) ходил Александр Ярославич с новгородцами на Немии, и биса с ними на Чудском озере у Ворониа каме, и победил Александр, и гони по леду 7 верст» ${ }^{34}$. Але знизу сторінки $\mathbf{5 2 3}$ цього літопису міститься дуже маленька примітка про те, що раніше в цій оповіді було зафіксоване ім'я Андрія замість Олександра. Тобто «сумлінний» переписувач, якому наказали викреслити із літопису ім'я Андрія та підмінити його ім'ям Олександра, вказав на підміну, зазначивши, що надане в оригіналі раніше ім'я Андрія було помилковим.

Скоріше за все, помилки не було, і саме Андрій Ярославович справедливо був вказаний як головний переможець у битві 3 тевтонцями. А пізніше автор «Суздальской летописи по Академическому списку» скоїв фальсифікацію. Академік О. Шахматов взагалі вважав «Суздальскую летопись по Академическому списку» компіляцією із трьох джерел ${ }^{35}$. Він пояснив, що текст цього літопису 3 відомостями про події від початку створення світу до 6714 року

${ }^{33}$ Полное собрание русских летописей (ПСРЛ). Т. І. Издание 2-е. Лаврентьевская летопись. Ленинград, 1926-1928. Вып. 2: Суздальская летопись по Лаврентьевскому списку. Ленинград, 1927. С. 326. URL: http://psrl.csu.ru/toms/Tom_01.shtml (дата звернення: 31.05.2020).

34 Полное собрание русских летописей (ПСРЛ). Т. І. Издание 2-е. Лаврентьевская летопись. Ленинград, 1926-1928. Вып. 3: Приложения. Продолжение Суздальской летописи по Академическому списку. Ленинград, 1928. С. 523. URL: http://psrl.csu.ru/toms/Tom_01.shtml (дата звернення: 31.05.2020).

35 Шахматов А.А. Ермолинская летопись и Ростовский владычный свод. СанктПетербург, 1904.

Шахматов А.А. Обозрение русских летописных сводов XIV-XVI вв. Москва, Ленинград, 1938. С. 146-150. 
запозичений із спільного з «Радзивиловской летописью» протографа, інформація про події, що відбулися у домонгольський період, переписані із «Софийской первой летописи старшего извода», а статті про події після монгольсько-татарського завоювання містять фрагменти скороченого «Ростовского владыческого свода».

Також О. Шахматов визначив, що відредагований фрагмент «Ростовского владыческого свода» про початок князювання батька Олександра Невського (Ярослава Всеволодовича) неавтентичний, і був вставлений переписувачем до Академічного літописного зводу у XV столітті. Сфальсифікувавши інформацію про справжнього переможця у військових подіях на Чудському озері, переписувач виконав політичне замовлення московських царів, які вели свій родовід від Олександра Ярославовича, а не від його брата Андрія ${ }^{36}$.

Порівнюючи свідчення іноземного хроніста із текстами новгородськосуздальських літописів, в авторки склалося враження про велику невідповідність описів військових звитяг Олександра Невського. Наприклад, згідно з текстом лівонської хроніки, у 1241 році Псков звільнив його молодший Андрій Ярославович, а у квітні 1242 року, після грабіжницького рейду суздальського князя Олександра, відбулася невелика сутичка його загонів із тевтонцями. Однак автори літописів стверджують, що Псков був звільнений виключно завдяки новгородському князю Олександру Ярославовичу, а також приписують йому всі звитяги у боротьбі з лицарями. Правда, з невеликою «виправленою помилкою» про головну роль у перемозі на Чудському озері військ Андрія Ярославовича.

\section{6. Міф про місце битви 3 тевтонцями 5 квітня 1242 року}

Зазначимо також, що й досі не знайдене місце, де відбувалася битва. Згідно з офіційною версією московських літописців, Олександр бився із німцями саме на льоду Чудського озера, переміг їх та переслідував по льоду сім верст. Квітневий лід не витримав, і закуті в залізо німецькі лицарі провалилися під лід та потонули. Але організована в СРСР наприкінці 50-х - на початку $60-\mathrm{x}$ років XX століття академічна експедиція під керівництвом військового історика Г. Караєва, не виявила жодних матеріальних слідів цього «побоїща» - ні кісток від загиблих воїнів та коней, ні озброєння ${ }^{37}$. Шукали також Воронячий

${ }^{36}$ Шахматов А.А. Ермолинская летопись и Ростовский владычный свод. СанктПетербург, 1904.

Шахматов А.А. Обозрение русских летописных сводов XIV-XVI вв. Москва, Ленинград, 1938. С. 146-150.

${ }^{37}$ Караев Г.Н. (отв. ред.) и др. Ледовое побоище 1242 года. Труды комплексной экспедиции по уточнению места Ледового побоища. Ленинград, 1966. 254 c. URL: http://ледовое-побоище.pф/library/trud-1242 (дата звернення: 31.10.2020). 
камінь, згаданий літописцями, біля якого нібито відбулася битва. Але експедиція підтвердила існування лише Воронячого острова у південній частині Чудського озера.

Таку цілковиту невдачу пошуків керівник експедиції пояснив досить парадоксально. Мовляв, Воронячий камінь із часом міг зруйнуватися вітрами, а загиблих воїнів за середньовічними традиціями німці відвезли з собою, щоб поховати в рідній землі. Таке безглузде пояснення не витримує ніякої критики. Яким чином у середні віки, не маючи водолазного спорядження, лицарі-тевтонці знайшли та підняли на поверхню всіх без винятку затонулих воїнів, їхнє озброєння та коней? Навіть у наш час це неймовірно складне та важке для виконання завдання. Як пояснює історик О. Нестеренко, відсутність на дні Чудського озера останків воїнів та їхнього озброєння пояснюється тим, що битва відбулася на іншій території. Його підтримує й дослідник К. Жуков, який стверджує, що й досі достеменно невідомо місце, де відбувалася битва Рюриковичів із німецькими лицарями ${ }^{38}$.

Теж саме стверджує автор «Старшей Ливонской рифмованой хроники». Він інформує, що вбиті під час бою «падали на траву» ${ }^{39}$ і не надав жодного свідчення про те, що лицарі провалилися під лід. Тобто маємо невідповідність свідчень лівонського хроніста та інформації, наданої московськими літописцями про місце події. Керівник академічної експедиції Г. Караєв намагався пояснити згадку хроніста про траву як про місце падіння вбитих тевтонців. Він стверджував, що травою можна вважати прибережний очерет, що пробивався 3-під льоду на мілководді озера. Саме там, стверджує дослідник, і відбулася битва ${ }^{40}$.

На нашу думку, закуті у важку броню тевтонські рицарі навряд чи стали б випробовувати міцність льоду та воювати на ньому. Тевтонські лицарі мали великий військовий досвід ведення боїв у суворих північних умовах, тому їхня спроба проводити військову операцію на льоду видається вельми дивною.

Перебільшеннями можна вважати також свідчення московських літописців про тисячі загиблих лицарів. Лівонський хроніст надає зовсім інші цифри: під час битви 3 князем Олександром загинуло 20 тевтонських лицарів і 6 було взято в полон ${ }^{41}$. Більшість науковців

38 Жуков К.А. Древняя Русь. От Рюрика до Батыя. Питер : Пресс. 2000. 288 с.

39 Старшая ливонская рифмованная хроника. Средневековые исторические источники востока и запада. С. 2240-2265. URL: http://www.vostlit.info/Texts/rus12/ Livl_Alte_Reimschronik/text1.phtml?id=827 (дата звернення: 31.05.2020).

${ }^{40}$ Караев Г.Н. (отв. ред.) и др. Ледовое побоище 1242 года. Труды комплексной экспедиции по уточнению места Ледового побоища. Ленинград, 1966. 254 c. URL: http://ледовое-побоище.pф/library/trud-1242 (дата звернення: 31.10.2020).

41 Старшая ливонская рифмованная хроника. Средневековые исторические источники востока и запада. С. 2260. URL: http://www.vostlit.info/Texts/rus12/ Livl_Alte_Reimschronik/text1.phtml?id=827 (дата звернення: 31.05.2020). 
піддають сумніву сюжет 3 агіографічної «Повести о житии... Александра» про подальше переслідування переможцями німців по льодовій поверхні Чудського озера, де відстань від берега до берега в місці передбачуваної битви становить всього два кілометри.

На думку дослідника І. Данилевського. ця історія була запозичена літописцем $з$ опису більш пізньої та масштабної Раковорської битви, що відбулася у 1268 році. Авторка поділяє думку I. Данилевського, який стверджує, що цифра учасників битви як із боку переможців, так і переможених, яка вказана у «Повести о житии ...», значно перебільшена. Він вважає, що Олександр міг привести за собою максимум 800 осіб. Це збігається зі свідченнями лівонського хроніста, який стверджував, що зіткнення відбулося не на озері, а на суші, і що в ньому було задіяна нечисленна кількість воїнів ${ }^{42}$.

\section{ВИСНОВКИ}

В офіційних російських джерелах Невську битву та «Льодове побоїще» називають епохальними, вважаючи, що Олександр Ярославович, завдавши нищівної поразки шведам та лицарям-тевтонцям, зупинив хрестовий похід католиків на Русь. Ці військові звитяги трактують як героїчну оборону західних кордонів православної Вітчизни від папської агресії і вважають вирішальним поворотом у відносинах між Руссю і Заходом.

Однак, аналізуючи відомості із «Новгородской первой летописи старшего извода» i «Повести о житии...», можна стверджувати, що зроблений їхніми авторами опис битви зовсім не відповідає свідченням іноземного хроніста, а також й досі не підкріплений будь-якими артефактами.

Багато епізодів цих битв, згаданих у «Повести о житии... Александра» та московських літописних версіях, не відповідають дійсності і можуть вважатися плодом авторської уяви. У них істотно перебільшується реальна чисельність учасників битв, підміняються головні герої та діючі особи, грабіжницькі військові рейди Олександра Ярославовича проти сусідів прирівнюються до перемоги біблійних Мойсея над Амаліком і Давида над філістимлянами. Насправді події так званої «Невської битви» взагалі не згадуються західним хроністам. Це був розбійницький напад новгородських військ, очолюваних князем Олександром Ярославовичем, на шведських купців.

Кількість учасників іншого бою - епохального «Льодового побоїща» перебільшена в кілька разів, а також вигадане місце його

42 Данилевский И.Н. Ледовое побоище: смена образа. Отечественные записки. 2004. № 5. URL: http://www.strana-oz.ru/2004/5/ledovoe-poboishche-smena-obraza (дата звернення: 01.11.2020). 
проведення і свідомо забуте ім'я його головного переможця - князя Андрія. Натомість у московських літописах суздальський розбійник князь Олександр постає як новгородський князь Олександр Ярославович Невський - герой та захисник православної Вітчизни

У сучасній Росії продовжується героїзація його постаті. Так, російський дослідник О. Селезньов у 2016 році стверджував, що «сражение, данное иноземным захватчикам на льду Чудского озера князем Александром ...имеет важное государственное значение, так как ...позволило России сохранить веру, культуру, язык, традиции и обычаи всех народов, что жили тогда на русской земле» ${ }^{43}$. Тому стає зрозумілим, чому Патріарх Московський Кирило (Гундяєв) у 2016 році визнав Олександра Невського небесним покровителем Сухопутних військ Російської Федерації. На жаль, міфологізований образ князя Олександра Невського продовжують використовувати для формування в сучасних росіян саме такого войовничого патріотизму, який Л. Толстой вважав почуттям аморальним, грубим, ганебним, шкідливим та поганим.

\section{АНОТАЦІЯ}

В історичній науці путінської Росії створюються міфи про «героїчні діяння» окремих постатей вз метою возвеличення власного імперського минулого. У цій статті авторка проаналізувала міфологеми про діяльність культової постаті російської історіографії - князя Олександра Невського. Спираючись на свідчення із літописів та західноєвропейських хронік, авторка довела безпідставність героїзації військових звитяг Олександра Ярославовича в «епохальних битвах» проти шведів та німців у 1240 та 1242 роках.

\section{ЛІТЕРАТУРА}

1. Данилевский И.Н. Ледовое побоище: смена образа. Отечественные записки. 2004. № 5. URL: http://www.strana-oz.ru/2004/5/ledovoepoboishche-smena-obraza (дата звернення: 01.11.2020)

2. Жуков К.А. Древняя Русь. От Рюрика до Батыя. Питер : Пресс. 2000. 288 c.

3. Караев Г.Н. (отв. ред.) и др. Ледовое побоище 1242 года. Труды комплексной экспедиции по уточнению места Ледового побоища. Ленинград, 1966. 254 c. URL: http://ледовое-побоище.pф/library/trud1242 (дата звернення: 31.10.2020)

4. Литература и культура Древней Руси: Словарь-справочник / О.М. Анисимова, В.В. Кусков, М.П. Одесский, П.В. Пятнов. Под ред.

\footnotetext{
${ }^{43}$ Селезнев А.А. Ледовое побоище, Кобылье Городище - мосты памяти. Псковский военно-исторический вестник. Вып. 2. История и археология. Псков, 2016.
} 
В.В. Кускова. Москва, 1994. С. 42. URL: http://history.org.ua/LiberUA/506-002874-7/5-06-002874-7.pdf (дата звернення: 30.10.2020)

5. Нестеренко А.Н. Александр Невский. Кто победил в Ледовом побоище. Москва, 2006. URL: https://may.alleng.org/d/hist/hist093.htm. (дата звернення: 30.10.2020)

6. Ніколаюк Т.А. Міфологізовані правителі Московії. Частина 1. Дмитро Донський - анафемований святий. Практична філософія. 2019. № 2. С. 108-113.

7. Ніколаюк Т.А. Міфологізовані правителі Московії. Частина 2. Міфологеми про антитатарську діяльність московського князя Дмитра Івановича. Практична філософія. 2019. № 4. С. 90-99.

8. Ніколаюк Т.А. Світоглядні міфологеми у тлумаченні історичного минулого України та Росії. Частина 1. Практична філософія. 2018. № 4. С. $88-100$.

9. Ніколаюк Т.А. Світоглядні міфологеми у тлумаченні історичного минулого України та Росії. Частина 2. Практична філософія. 2019. № 1. С. $88-103$.

10. Повесть о житии и о храбрости благоверного и великого князя Александра / Подготовка текста, перевод и комментарии В.И. Охотниковой. Библиотека литературы древней Руси. Том 5. Электронные публикации Института русской литературы (Пушкинского Дома) РАН. C. 1. URL: http://lib.pushkinskijdom.ru/Default.aspx?tabid=4962 (дата звернення: 31.10.2020)

11. Полное собрание русских летописей (ПСРЛ). Новгородские и Псковские летописи. Новгородская четвертая летопись. T. IV. СанктПетербург, 1848. C. 35. URL: http://psrl.csu.ru/toms/Tom_04.shtml (дата звернення 31.05.2020)

12. Полное собрание русских летописей (ПСРЛ). Новгородские летописи. Т. III. Издание 1-е. Санкт-Петербург, 1841. Новгородская первая летопись. С. 52-53. URL: http://psrl.csu.ru/toms/Tom_03.shtml (дата звернення 31.05.2020)

13. Полное собрание русских летописей (ПСРЛ). Т. І. Издание 2-е. Лаврентьевская летопись. Ленинград, 1926-1928. Вып. 2: Суздальская летопись по Лаврентьевскому списку. Ленинград, 1927. С. 326. URL: http://psrl.csu.ru/toms/Tom_01.shtml (дата звернення: 31.05.2020)

14. Полное собрание русских летописей (ПСРЛ). Т. І. Издание 2-е. Лаврентьевская летопись. Ленинград, 1926-1928. Вып. 3: Приложения. Продолжение Суздальской летописи по Академическому списку. Ленинград, 1928. C. 523. URL: http://psrl.csu.ru/toms/Tom_01.shtml (дата звернення: 31.05.2020) 
15. Рамм Б.Я. Папство и Русь в X-XV вв. Москва-Ленинград, 1959. URL: http://a-nevsky.ru/library/papstvo-i-rus8.html (дата звернення: $02.11 .2020)$

16. Соловьев С.М. История России с древнейших времен. Соловьев С.М. Сочинения. Москва, 1993. Т. 3. С. 174.

17. Старшая ливонская рифмованная хроника. Средневековые исторические источники востока и запада. С. 2075-2160. URL: http://www.vostlit.info/Texts/rus12/Livl_Alte_Reimschronik/text1.phtml?id $=827$ (дата звернення: 31.05.2020)

18. Тихомиров М.Н. Сражение на Неве. Военно-исторический журнал. 1940. № 7 (12). С. 99.

19. Толстой Л.Н. Патриотизм и правительство. Полное собрание сочинений в 90 томах. Т. 90. Дневники. Письма, 1835-1910. Москва, 1958. 474 c. URL: http://tolstoy.ru/upload/iblock/e8e/90_tom.pdf (дата звернення: 31.10.2020)

20. Толстой Л.Н. Христианство и патриотизм. Полное собрание сочинений в 90 томах. Т. 39. Статьи 1893-1898. Москва, 1956. С. 60. URL: $\quad$ http://tolstoy.ru/upload/iblock/08c/08c43ef984906280a7a38dd797 d2af99.pdf (дата звернення: 31.05.2020)

21. Феннел Дж. Кризис средневековой Руси. 1200-1304 гг. Москва, 1989. 291 c. URL: http://booksonline.com.ua/view.php?book=35808 (дата звернення: 31.05.2020)

22. Хроника Эрика / Составитель, ответственный редактор и редактор перевода А.А. Сванидзе. Перевод со старошведского А.Ю. Желтухина. 2-е издание, исправленное и дополненное. Москва, 1999. $254 \mathrm{c}$.

23. Шахматов А.А. Ермолинская летопись и Ростовский владычный свод. Санкт-Петербург, 1904.

24. Шахматов А.А. Обозрение русских летописных сводов XIV-XVI вв. Москва, Ленинград, 1938. С. 146-150.

\section{Information about the author:}

Nikolaiuk T. A.,

Candidate of Historical Sciences, Associate Professor, Head of the Department of Culture and Socio-humanitarian Disciplines National Academy of Fine Arts and Architecture 20, Voznesensky Uzviz, Kyiv, 04053, Ukraine 